\title{
Blue Water Footprints of Ontario Dairy Farms
}

\author{
Mariam Al-Bahouh ${ }^{1,2, *}$, Vern Osborne ${ }^{3}$, Tom Wright ${ }^{4}$, Mike Dixon ${ }^{2}$, Andrew VanderZaag ${ }^{5}$ and Robert Gordon ${ }^{6}$ \\ 1 Environment and Life Sciences Research Center, Kuwait Institute for Scientific Research, Shuwaikh, \\ P.O. Box 24885, Safat 13109, Kuwait \\ 2 School of Environmental Sciences, University of Guelph, Guelph, ON N1G 2W1, Canada; \\ mdixon@uoguelph.ca \\ 3 Department of Animal Bio-Sciences, University of Guelph, Guelph, ON N1G 2W1, Canada; \\ vosborne@uoguelph.ca \\ 4 Agricultural Development Branch, Ontario Ministry of Agriculture, Food and Rural Affairs, \\ Guelph, ON N1G 4Y2, Canada; tom.wright@ontario.ca \\ 5 Ottawa Research and Development Centre, Agriculture and Agri-Food Canada, 960 Carling Avenue, \\ Ottawa, ON K1A 0C6, Canada; andrew.vanderzaag@canada.ca \\ 6 School of the Environment, University of Windsor, Windsor, ON N9B 3P4, Canada; rogordon@uwindsor.ca \\ * Correspondence: malbahou@uoguelph.ca
}

check for updates

Citation: Al-Bahouh, M.; Osborne, V.; Wright, T.; Dixon, M.; VanderZaag, A.; Gordon, R. Blue Water Footprints of Ontario Dairy Farms. Water 2021, 13, 2230. https://doi.org/10.3390/ w13162230

Academic Editor:

Winnie Gerbens-Leenes

Received: 4 June 2021

Accepted: 13 August 2021

Published: 16 August 2021

Publisher's Note: MDPI stays neutral with regard to jurisdictional claims in published maps and institutional affiliations.

Copyright: (c) 2021 by the authors. Licensee MDPI, Basel, Switzerland. This article is an open access article distributed under the terms and conditions of the Creative Commons Attribution (CC BY) license (https:// creativecommons.org/licenses/by/ $4.0 /)$.

\begin{abstract}
The blue water footprint (WF) is an indicator of freshwater required to produce a given end product. Determining the blue WF for milk production, the seasonal water use and the impact of water conservation are important sustainability considerations for the dairy industry in Ontario (Canada). In this study, a water footprint network (WFN) method was used to calculate the seasonal blue WF's from in-barn water use data and the fat-protein-corrected milk (FPCM) production. Various water conservation options were estimated using the AgriSuite software. Results showed that the total water use ( $\mathrm{L}$ of water $\cdot \mathrm{cow}^{-1} \cdot \mathrm{d}^{-1}$ ) and the average blue WF ( $\mathrm{L}$ of water $\cdot \mathrm{kg}^{-1}$ of FPCM) were $246.3 \pm 6.8 \mathrm{~L} \cdot \mathrm{cow}^{-1} \cdot \mathrm{d}^{-1}$ and $7.4 \pm 0.2 \mathrm{~L} \cdot \mathrm{kg}^{-1}$, respectively. The total water use and the blue WF could be reduced to $182.7 \pm 5.1 \mathrm{~L} \cdot \mathrm{cow}^{-1} \cdot \mathrm{d}^{-1}\left(25.8 \%\right.$ reduction) and $5.8 \pm 0.1 \mathrm{~L} \cdot \mathrm{kg}^{-1}$ (21.6\% reduction), respectively, through adaptive water conservation measures as the reuse of the plate cooler and milk house water. For example, conservation practices could reduce the milk house wash water use from $74.3 \pm 8.8 \mathrm{~L} \cdot \mathrm{cow}^{-1} \cdot \mathrm{d}^{-1}$ to $16.6 \pm 0.1 \mathrm{~L} \cdot \mathrm{cow}^{-1} \cdot \mathrm{d}^{-1}(77.7 \%$ overall reduction).
\end{abstract}

Keywords: dairy farming; blue water footprint (WF); fat-protein-corrected milk (FPCM); AgriSuite software; water conservation

\section{Introduction}

Dairy farms are considered to be water intensive production systems due to their significant fresh water requirements [1]. Mekonnen and Hoekstra [2] estimated that the water required for global animal production was $2422 \mathrm{Gm}^{3} \cdot \mathrm{y}^{-1}$ with $19 \%$ utilized for dairy production. The expansion of dairy production to support the increasing global demand for milk and milk products has created further pressures on water resources and competition between the water and food supply sectors [3]. It is, therefore, important to quantify the rate of water use and the water footprint (WF) of dairy production systems to assist with better understanding, quantifying and improving the sustainability of the sector [4].

The WF is the volume of water required for the production of a given final product [5]. For rainfed dairy operations, such as those in Ontario, Canada, the WF reflects the drinking, cooling and cleaning water used for dairy cows and the indirect water embedded in feed production. In the current study, we focus on the blue WF that addresses the direct on-farm water requirements to produce milk (i.e., the fat-protein-corrected milk-FPCM).

The blue WF is calculated using site-specific collected data or various modelling approaches [6]. Modelling systems can also be used to evaluate the benefits of conservation practices to reduce the amount of water utilized in a production system. AgriSuite [7], 
developed by the Ontario Ministry of Agriculture, Food and Rural Affairs (OMAFRA) as part of their "Nutrient Management Planning Software" (NMAN) is one such example. The decision support system [7] allows the user to assess approaches to manage and decrease on farm water use.

Despite the high demand for fresh water resources needed for milk production, few studies have addressed water use, the resulting WF and the impacts of various conservation practices. In addition, a shortcoming has been the use of historical information [2,4] and governmental data with no indication of the method of calculation [8] which affects the accuracy and repeatability of the assessment.

Assessing water use is important for the dairy sector even in water-rich countries such as Canada [9]. This is due to the need for accurate WF values that can help to reveal practices to increase the efficiency and productivity of water use. Indeed, the water use associated with various milking systems has not been well characterized [10] and limited studies have been conducted to assess the water use of dairy farms in North America [11] and Canada [12].

Improving our understanding of water use on dairy farms is crucial to develop strategies that support their overall sustainability. The objectives of this study are, therefore, to: (i) assess the seasonal water use and the blue WF on typical dairy production systems in Ontario, Canada, and (ii) determine the relative impact of water conservation strategies on both the water use and the WF.

\section{Materials and Methods}

\subsection{Farm-Specific Data for Blue WF Calculation}

The WF is a decision support framework that has been developed to help manage water use within the supply chain. It generally includes direct and indirect water uses related to a production system. It helps to highlight the importance of certain practices to draw conclusions about water management. Although a full WF assessment would include water involved in production of feed, electricity, etc., this study focused on the in-barn blue water component so that relevant farm practices can be highlighted.

The blue WF's of dairy farms in Ontario across different seasons were estimated using the Water Footprint Network (WFN) method [13]. The blue WF provides specific estimates of the amount of water used in specific region. It is a direct method to assess the system and evaluate sustainability and it is applicable to many agricultural activities. The blue WF of milk production was calculated per unit $\mathrm{kg}$ of FPCM $[4,14]$. This was achieved by dividing the FPCM [2] from the direct farm water use (washing, spraying/cooling and drinking water of dairy cattle, including lactating cows, dry cows, heifers and calves). The blue WF ( $\mathrm{L} \mathrm{H}_{2} \mathrm{O} \mathrm{kg}^{-1}$ FPCM) was expressed as:

$$
\text { Blue WF }=\left(W_{(\text {drinking })}+W_{(\text {washing })}+W_{(\text {spray })}\right) / F P C M
$$

where $W_{(\text {drinking })}=$ water intake consumption $\left(\mathrm{L} \cdot \mathrm{cow}^{-1} \cdot \mathrm{d}^{-1}\right) ; W_{(\text {washing })}=$ milk house wash water generated $\left(\mathrm{L} \cdot \mathrm{cow}^{-1} \cdot \mathrm{d}^{-1}\right) ; W_{(\text {spray })}=$ spray water for cooling $\left(\mathrm{L} \cdot \mathrm{cow}^{-1} \cdot \mathrm{d}^{-1}\right)$; $F P C M=$ fat-protein-corrected milk $\left(\mathrm{kg} \cdot \mathrm{Cow}^{-1} \cdot \mathrm{d}^{-1}\right)$ based on IDF [15] estimated as:

$$
\text { FPCM }=\text { Milk }_{\text {yield }}\left[0.1226\left(\text { Milk }_{\text {fat } \%}\right)+0.0776\left(\text { Milk }_{\text {protein } \%}\right)+0.2534\right]
$$

where Milk yield $=$ milk yield $\left(\mathrm{kg} \cdot \mathrm{cow}^{-1} \cdot \mathrm{d}^{-1}\right) ;$ Milk $_{\text {fat } \%}=$ fat content of the milk $(\%)$;

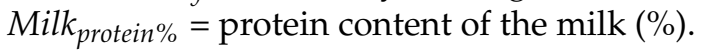

Monthly water use and milk production data from seven Ontario dairy farms were used and included 20 months (May 2013 to December 2014) of continuous total in-barn water utilization which included water intake (WI) of dairy cows and the water used for washing the milk house. The data were selected from the seven farms [16] as it included a complete description and information required to conduct the WF analysis. 
The annual milk yield (MY), protein (\%) and fat (\%) were obtained from Robinson et al. [16] and were rescaled to monthly data by multiplying each farm data $(\mathrm{x})$ by a correction factor $(\mathrm{k})$ to transform $(\mathrm{x})$ to $\mathrm{f}(\mathrm{x})$ where both $(\mathrm{k})$ and $(\mathrm{x})$ are measured data $[17,18]$. The patterns of monthly MY, protein (\%) and fat (\%) of Holstein dairy cows over 12 months under North American weather conditions were adopted from Salfer et al. [19]. These data were extracted using the "web plot digitizer" software and used to calculate the monthly MY, fat (\%) and protein (\%) contents for each dairy farm [16].

Meteorological data, MY, fat (\%) and protein (\%) contents were used to calculate the water intake (WI) and spray water based on Equations (3), (4) and (6) below.

The WI per lactating cow was calculated using the average of two WI equations below; Equation (3) from Osborne [20] and Equation (4) from Murphy et al. [21]. Osborne [20] is based on the ratio of water to milk from 14 previously published studies and described as:

$$
W I=2.60 F P C M
$$

and Murphy et al. [21] expressed as:

$$
W I=23.00+2.38 D M I+0.64 F P C M
$$

where WI: water intake $\left(\mathrm{L} \cdot \mathrm{cow}^{-1} \cdot \mathrm{d}^{-1}\right) ; D M I$ : dry matter intake $(\mathrm{kg})$.

The DMI was calculated based on Chase and Sniffen [22], which is expressed as:

$$
D M I=0.0185 B W T+0.305 F P C M
$$

assuming that body weight (BWT) of Holstein dairy cows in Canada is $680 \mathrm{~kg}$ [23].

The water consumed by other animal categories (i.e., calves, heifers, dry cows) was obtained from Ward and McKague [24] and Le Riche et al. [25] (Table 1). The average of these values was extended to compute the monthly WI of each of the additional animal categories (i.e., dry cows, heifers and calves). The WI from different seasons was determined using the multiplicative factor from WI data of lactating cows, taking into account the seasonal effect assuming that all animal categories were exposed to the same environmental conditions [26,27].

Table 1. Water intake per animal category $\left(\mathrm{L} \cdot \mathrm{cow}^{-1} \cdot \mathrm{d}^{-1}\right)$ of confined dairy farming systems (calves, heifers and dry cows) in Ontario, Canada.

\begin{tabular}{cccc}
\hline & $\begin{array}{c}\text { Calves } \\
\left(\mathbf{L} \cdot \text { cow }^{-\mathbf{1}} \cdot \mathbf{d}^{-\mathbf{1}} \mathbf{)}\right.\end{array}$ & $\begin{array}{c}\text { Heifers } \\
\left(\mathbf{L} \cdot \mathbf{c o w}^{-\mathbf{1}} \cdot \mathbf{d}^{-\mathbf{1}} \mathbf{)}\right.\end{array}$ & $\begin{array}{c}\text { Dry Cows } \\
\left(\mathbf{L} \cdot \mathbf{c o w}^{\mathbf{1}} \cdot \mathbf{d}^{-\mathbf{1}} \mathbf{)}\right.\end{array}$ \\
\hline${\text { Le Riche et al. [25] }{ }^{\mathbf{a}}}_{\text {Ward and McKague [24] }}^{\mathbf{b}}$ & 12.0 & 22.0 & 36.0 \\
Average & 9.1 & 25.4 & 41.5 \\
& 10.6 & 23.7 & 38.8 \\
\hline
\end{tabular}

a Average water consumption over 1-year period in confined dairy farming system in Eastern ON; number of calves (200), dry cows (54) and heifers (240). ${ }^{\mathrm{b}}$ Average water consumption on a daily basis over a year in ON (numbers of different animal categories were not mentioned).

The water content of the feed based on the main components of diets in Ontario was sourced from the University of Guelph Elora Dairy Research Station (Table 2).

Table 2. Feed intake (kg), dry matter intake (DMI, kg) and dietary water (DW, $\mathrm{kg}$ ) of different diets on confined dairy farms in Ontario, Canada.

\begin{tabular}{cccc}
\hline Ingredient & As Fed (kg) & DMI (kg) & DW (kg) \\
\hline Lactating Cows & 52.5 & 25.3 & 27.2 \\
Dry Cows & 27.4 & 15.6 & 11.8 \\
Heifers (2-24 mo) & 28.1 & 11.8 & 16.3 \\
Calves (birth-2 mo) & 1.1 & 1.0 & 0.1 \\
\hline
\end{tabular}


The amount of daily spray water used for cooling purposes on each dairy farm was calculated based on Le Riche et al. [25]:

$$
\text { Spray Water }=658.79 \mathrm{~T}-11250
$$

The amount of spray water $\left(\mathrm{L} \cdot \mathrm{cow}^{-1} \cdot \mathrm{d}^{-1}\right)$ was assumed to be negligible $\left(0.0 \mathrm{~L} \cdot \mathrm{cow}^{-1} \cdot \mathrm{d}^{-1}\right)$ unless the average air temperature (T) was $\geq 21^{\circ} \mathrm{C}$. The estimated amount of spray water used was divided by the number of animals in the milking herd to estimate a value per cow.

Meteorological parameters, including the daily $T\left({ }^{\circ} \mathrm{C}\right)$ and relative humidity $(R H, \%)$, were obtained from NASA [28] based on coordinates of the nearest weather station for each Ontario farm [16]. The meteorological data were used to calculate the TemperatureHumidity Index (THI) based on Lefcourt and Schmidtmann [29]:

$$
T H I=0.8 T+R H(T-14.30)+46.3
$$

Additionally, $T$ and $R H$ were used to calculate the adjusted $T H I\left(T H I_{a d j}\right)$, which is the change in apparent THI due to high-pressure evaporative cooling and was only used during the summer months based on St-Pierre et al. [30]:

$$
\mathrm{THI}_{\text {adj }}=-11.7-(0.16 \mathrm{~T})+(0.18 \mathrm{RH})
$$

where $T$ is the dry bulb temperature $\left({ }^{\circ} \mathrm{C}\right)$ and $\mathrm{RH}$ is the relative humidity in decimal form.

\subsection{Using AgriSuite for Simulating Water Conservation Impacts}

AgriSuite [7] was used to determine the annual wash water generated from milking centers and the potential water conservation benefits in terms of net water savings. The calculation of farm water use using AgriSuite relied on descriptive information and empirical data for the type of milking system, the size of the milking herd and the use of plate coolers (or not) [7]. These characteristics were varied among the Ontario farms described by Robinson et al. [16]. The simulated scenario by AgriSuite involved reusing water from the plate cooler and recycling milk house wash water to clean the holding areas. The AgriSuite software was developed by agricultural engineers using Ontario data to develop and test the equations related to common production practices to help inform compliance with provincial government regulations and best management practice recommendations.

\section{Statistical Analysis}

R statistical software 3.4 for Windows [31] was used to calculate the seasonal and farm management effects on the blue WF using linear regression. The effects of season, $\mathrm{THI}_{\mathrm{adj}}$ and farm were independent variable(s) on the average WI, MY, milk house wash water, spray water, total farm water use, FPCM and blue WF as dependent variable(s). The linear regression model was:

$$
Y=B_{0}+B_{1} X_{1}+B_{2} X_{2}+B_{3} X_{3}+e
$$

where $Y$ (dependent variable) is the average WI, MY, milk house wash water, spray water, total farm water use, FPCM and blue WF; $B_{0}$ : coefficient of constant (intercept); $B_{\mathrm{n}}$ : slope; $X_{\mathrm{n}}$ : value of independent variable(s); $e$ : error. Significant was considered when the $p$-value was $\leq 0.05$.

\section{Results and Discussion}

\subsection{Weather Conditions in Ontario}

The average values of $\mathrm{T}\left({ }^{\circ} \mathrm{C}\right), \mathrm{RH}(\%), \mathrm{THI}$ and $\mathrm{THI}_{\mathrm{adj}}$ during the study for different regions in Ontario where the farms are located are provided in Table 3. 
Table 3. Average meteorological conditions of different dairy farm locations in Ontario, Canada, including temperature $\left(\mathrm{T},{ }^{\circ} \mathrm{C}\right)$, relative humidity $(\mathrm{RH}, \%)$, $\mathrm{THI}$ and adjusted $\mathrm{THI}\left(\mathrm{THI}_{\mathrm{adj}}\right)$.

\begin{tabular}{|c|c|c|c|}
\hline $\begin{array}{ll}\text { Parameter } & \text { Region } \\
\end{array}$ & Napanee $^{a}$ & Embro $^{b}$ & Ottawa $^{c}$ \\
\hline $\mathrm{T}\left({ }^{\circ} \mathrm{C}\right)$ & $9.7 \pm 2.1$ & $8.9 \pm 2.4$ & $7.7 \pm 2.6$ \\
\hline RH (\%) & $77.9 \pm 0.8$ & $77.1 \pm 1.2$ & $79.5 \pm 0.9$ \\
\hline THI & $50.1 \pm 3.4$ & $48.8 \pm 3.8$ & $46.8 \pm 4.2$ \\
\hline $\mathrm{THI}_{\text {adj (summer only) }}$ & $45.7 \pm 2.6$ & $44.3 \pm 13.5$ & $42.4 \pm 3.3$ \\
\hline
\end{tabular}

${ }^{\mathrm{a}}$ Farm H; ${ }^{\mathrm{b}}$ Farm P; ${ }^{\mathrm{C}}$ Farm A, D, G, M and Q (detailed information about each farm in Robinson et al. [16]).

\subsection{Water Intake of Different Animal Categories on Dairy Farms in Ontario, Canada}

The average daily WI of different animal categories on dairy farms in Ontario is shown in Table 4 . Water intake $\left(\mathrm{WI}, \mathrm{L} \cdot \mathrm{cow}^{-1} \cdot \mathrm{d}^{-1}\right.$ ) of lactating cows, dry cows, heifers and calves, including dietary water were $121.3 \pm 0.7,50.9 \pm 0.3,41.2 \pm 1.4$ and $10.5 \pm 0.1 \mathrm{~L} \cdot \mathrm{cow}^{-1} \cdot \mathrm{d}^{-1}$, respectively.

Table 4. Water intake $\left(\mathrm{WI}, \mathrm{L} \cdot \mathrm{cow}^{-1} \cdot \mathrm{d}^{-1}\right)$, dietary water $\left(\mathrm{DW}, \mathrm{L} \cdot \mathrm{cow}^{-1} \cdot \mathrm{d}^{-1}\right)$ and total water $\left(\mathrm{L} \cdot \mathrm{Cow}^{-1} \cdot \mathrm{d}^{-1}\right)$ of different animal categories on dairy farms in Ontario, Canada.

\begin{tabular}{|c|c|c|c|}
\hline & WI & DW & Total \\
\hline Lactating cows $\left(\mathrm{L} \cdot \operatorname{cow}^{-1} \cdot \mathrm{d}^{-1}\right)$ & $93.8 \pm 0.7^{a *}$ & $27.5^{\mathrm{b}}$ & 121.3 \\
\hline Dry cows $\left(L \cdot \operatorname{cow}^{-1} \cdot d^{-1}\right)$ & $39.1 \pm 0.3^{c}$ & $11.8^{\mathrm{d}}$ & 50.9 \\
\hline $\begin{array}{l}\text { Heifers }\left(\mathrm{L} \cdot \text { cow }^{-1} \cdot \mathrm{d}^{-1}\right) \\
\quad(2-24 \text { month })\end{array}$ & $24.9 \pm 1.4^{\mathrm{c}}$ & $16.3^{\mathrm{d}}$ & 41.2 \\
\hline $\begin{array}{l}\text { Calves }\left(\mathrm{L} \cdot \operatorname{cow}^{-1} \cdot \mathrm{d}^{-1}\right) \\
(<2 \mathrm{month})\end{array}$ & $10.4 \pm 0.1^{\mathrm{c}}$ & $0.1^{\mathrm{d}}$ & 10.5 \\
\hline
\end{tabular}

* Mean \pm SE (no. of lactating cows in 7 farms: $\mathrm{A}=126 ; \mathrm{D}=65 ; \mathrm{G}=155 ; \mathrm{H}=98 ; \mathrm{M}=118 ; \mathrm{P}=104 ; \mathrm{Q}=187$ $n=$ average number of cows 121.9) [16]. ${ }^{\text {a }}$ Estimated values based on WI equations of Murphy et al. [21] and Osborne [20]. " Dietary water content of lactating cows' diet was adopted from "Efficient Dairy Genome Project" ( $n=20$ feed sample; May 2017-March 2019). ${ }^{c}$ Computed using multiplicative factor with reference average WI values of Le Riche et al. [25] and Ward and McKague [24]. ${ }^{\mathrm{d}}$ University of Guelph Elora Research Station diet.

The provision of sufficient water is important for optimal production [32]. The estimated values of WI by lactating and non-lactating cows in the current study were affected by several factors, including DMI, MY and weather conditions which agree with Cardot et al. [33]. The average WI of lactating cows was affected significantly $(p<0.001)$ by season and farm and was consistent with published data (Table 5).

Table 5. Published water intake $\left(\mathrm{WI}, \mathrm{L} \cdot \mathrm{Cow}^{-1} \cdot \mathrm{d}^{-1}\right)$ data of different animal categories on confined dairy farming systems in Ontario, Canada.

\begin{tabular}{cccc}
\hline & Le Riche et al. [25] ${ }^{\mathbf{a}}$ & Ward and McKague [24] $^{\mathbf{b}}$ & ${\text { Beaulieu et al. [34] }{ }^{\mathbf{c}}}$ \\
\hline Lactating cows & 114.0 & $87.0-102.0^{\mathrm{d}}$ & 90.0 \\
Dry cows & 36.0 & $114.0-136.0^{\mathrm{e}}$ & - \\
Heifers & 22.0 & $34.0-49.0$ & 25.0 \\
Calves & 12.0 & $14.4-36.3$ & 15.0 \\
\hline
\end{tabular}

a Number of lactating cows (419), dry cows (54), heifers (240) and calves (200). ${ }^{\mathrm{b}, \mathrm{c}}$ Numbers of different animal categories were not mentioned but the values estimated per animal. ${ }^{\mathrm{d}}$ WI based on $\mathrm{MY}=22.7 \mathrm{~L} \cdot \mathrm{cow}^{-1} \cdot \mathrm{d}^{-1}$. ${ }^{\mathrm{e}}$ WI based on $\mathrm{MY}=36.3 \mathrm{~L} \cdot \operatorname{cow}^{-1} \cdot \mathrm{d}^{-1}$.

\subsection{Seasonal Effect on Total Farm Water Use and Blue WF}

\subsubsection{Herd Size and Milk Production}

For Robinson et al. [16], the herd sizes ranged from 72 to 226 cows. The milking systems were rotary, robot, parallel, pipeline and swing-over and included both free and tie stall systems. The average MY was $34.5 \pm 0.3 \mathrm{~L} \cdot \mathrm{cow}^{-1} \cdot \mathrm{d}^{-1}$ and ranged from $32.4 \pm 0.5 \mathrm{~L} \cdot \mathrm{cow}^{-1} \cdot \mathrm{d}^{-1}$ in the winter to $37.5 \pm 0.7 \mathrm{~L} \cdot \mathrm{cow}^{-1} \cdot \mathrm{d}^{-1}$ in the summer. The 
average fat content of milk was $3.97 \pm 0.0 \%$ and ranged from $3.8 \pm 0.0 \%$ in the fall to $4.2 \pm 0.1 \%$ in the spring. The average protein content of milk was $3.2 \pm 0.0 \%$ and ranged from $3.0 \pm 0.0 \%$ in the summer to 3.3 in the spring $( \pm 0.0 \%)$ and winter $( \pm 0.1 \%)$. The variations in MY, fat and protein contents were related to the significant effect $(p<0.001)$ of seasons and THI along with the effect of different management practices.

VanderZaag et al. [35] found that the average MY in Eastern Ontario was $29.0 \mathrm{~L} \cdot \mathrm{cow}^{-1} \cdot \mathrm{d}^{-1}$, and varied from $28.0 \mathrm{~L} \cdot \mathrm{cow}^{-1} \cdot \mathrm{d}^{-1}$ in summer to $29.5 \mathrm{~L} \cdot \mathrm{cow}^{-1} \cdot \mathrm{d}^{-1}$ in winter. Our findings were comparable with Le Riche et al. [25], who found that the average MY on a free stall production system was $34.8 \pm 0.8 \mathrm{~kg} \cdot \mathrm{cow}^{-1} \cdot \mathrm{d}^{-1}$ with protein and fat contents of $3.2 \%$ and $3.8 \%$, respectively. Le Riche et al. [25] calculated the FPCM to be $33.6 \mathrm{~kg} \cdot \mathrm{cow}^{-1} \cdot \mathrm{d}^{-1}$ which is consistent with our estimates of FPCM $\left(33.9 \pm 0.3 \mathrm{~L} \cdot \mathrm{cow}^{-1} \cdot \mathrm{d}^{-1}\right)$. In addition, the results of the current study agreed with others [20,32] and reflects the positive correlation between MY and the whole farm water utilization (including WI and spray water) that aim to improve dairy cows' performance [36].

\subsubsection{Total Farm Water Use}

The main components of farm water use throughout the year are shown in Table 6. The total water use on confined Ontario dairy farms was significantly affected by the season $(p<0.001)$, farm management practices $(p<0.00)$ and $\mathrm{THI}_{\mathrm{adj}}(p<0.01)$. The total water use was estimated to be $246.3 \pm 6.8 \mathrm{~L} \cdot \mathrm{cow}^{-1} \cdot \mathrm{d}^{-1}$ of which $168.1 \pm 2.0 \mathrm{~L} \cdot \mathrm{cow}^{-1} \cdot \mathrm{d}^{-1}$ $(\sim 68.3 \%)$ was for WI, $74.3 \pm 8.8 \mathrm{~L} \cdot \mathrm{cow}^{-1} \cdot \mathrm{d}^{-1}(\sim 30.2 \%)$ for milking parlor washing and $1.7 \pm 0.4 \mathrm{~L} \cdot \mathrm{cow}^{-1} \cdot \mathrm{d}^{-1}(\sim 0.7 \%)$ for spray water. The wash water generated was comparable to Higham et al. [37] who estimated it to be $58.0 \mathrm{~L} \cdot \mathrm{cow}^{-1} \cdot \mathrm{d}^{-1}$.

Table 6. Meteorological conditions, including temperature $\left(\mathrm{T},{ }^{\circ} \mathrm{C}\right)$, relative humidity $(\mathrm{RH}, \%)$, THI and adjusted THI $\left(\mathrm{THI}_{\mathrm{adj}}\right)$; milk information, including milk yield (MY, kg), fat (\%), protein (\%) and FPCM $\left(\mathrm{kg} \cdot \mathrm{cow}^{-1} \cdot \mathrm{d}^{-1}\right)$; farm water utilization, including wash water $\left(\mathrm{L} \cdot \mathrm{cow}^{-1} \cdot \mathrm{d}^{-1}\right)$, water intake $\left(\mathrm{WI}, \mathrm{L} \cdot \mathrm{cow}^{-1} \cdot \mathrm{d}^{-1}\right)$, spray water $\left(\mathrm{L} \cdot \mathrm{cow}^{-1} \cdot \mathrm{d}^{-1}\right)$, total water use $\left(\mathrm{L} \cdot \mathrm{cow}^{-1} \cdot \mathrm{d}^{-1}\right)$ and blue WF $\left(\mathrm{L} \cdot \mathrm{kg}^{-1} \mathrm{FPCM}\right)$ of confined dairy farming systems in Ontario, Canada, for different seasons.

\begin{tabular}{|c|c|c|c|c|c|c|}
\hline Season $^{a}$ & Spring & Summer & Fall & Winter & Average $^{b}$ & SE \\
\hline \multicolumn{7}{|c|}{ Milk Production and Climatic Conditions } \\
\hline $\mathrm{T}\left({ }^{\circ} \mathrm{C}\right)$ & $3.8 \pm 1.8$ & $18.9 \pm 0.1$ & $8.9 \pm 0.9$ & $-7.9 \pm 0.7$ & 5.6 & 1.0 \\
\hline RH (\%) & $78.8 \pm 0.6$ & $76.5 \pm 0.6$ & $78.2 \pm 0.4$ & $85.1 \pm 0.3$ & 79.7 & 0.4 \\
\hline THI & $41.0 \pm 2.9$ & $65.2 \pm 0.2$ & $49.2 \pm 1.5$ & $21.3 \pm 1.1$ & 43.7 & 1.6 \\
\hline $\mathrm{THI}_{\mathrm{adj}}$ & - & $50.3 \pm 0.2$ & - & - & 50.3 & 0.2 \\
\hline MY (kg) c & $36.0 \pm 0.7$ & $37.5 \pm 0.7$ & $33.7 \pm 0.5$ & $32.4 \pm 0.5$ & 34.5 & 0.3 \\
\hline Fat $(\%)^{c}$ & $4.2 \pm 0.1$ & $4.0 \pm 0.0$ & $3.8 \pm 0.0$ & $4.1 \pm 0.0$ & 3.97 & 0.0 \\
\hline Protein $(\%)^{c}$ & $3.3 \pm 0.0$ & $3.0 \pm 0.02$ & $3.1 \pm 0.02$ & $3.3 \pm 0.1$ & 3.2 & 0.0 \\
\hline FPCM $\left(\mathrm{kg} \cdot \operatorname{cow}^{-1} \cdot \mathrm{d}^{-1}\right) \mathrm{d}$ & $36.7 \pm 0.7$ & $36.5 \pm 0.7$ & $32.2 \pm 0.4$ & $32.6 \pm 0.6$ & 33.9 & 0.3 \\
\hline \multicolumn{7}{|c|}{ Farm Water Utilization and the Blue WF } \\
\hline Wash water $\left(\mathrm{L} \cdot \mathrm{cow}^{-1} \cdot \mathrm{d}^{-1}\right) \mathrm{e}^{\mathrm{e}}$ & $55.6 \pm 12.1$ & $88.8 \pm 20.4$ & $89.9 \pm 13.9$ & $63.0 \pm 12.0$ & 74.3 & 8.8 \\
\hline$W I\left(L \cdot \operatorname{cow}^{-1} \cdot d^{-1}\right)^{f}$ & $(176.1 \pm 1.7)$ & $(176.4 \pm 1.3)$ & $(159.9 \pm 1.1)$ & $(168.2 \pm 7.3)$ & 168.1 & 2.0 \\
\hline Spray water $\left(L \cdot \operatorname{cow}^{-1} \cdot d^{-1}\right) g$ & $\mathrm{n} / \mathrm{a}$ & $8.8 \pm 1.1$ & $\mathrm{n} / \mathrm{a}$ & $\mathrm{n} / \mathrm{a}$ & 1.7 & 0.4 \\
\hline Total $\left(\mathrm{L} \cdot \operatorname{cow}^{-1} \cdot \mathrm{d}^{-1}\right)$ & $231.7 \pm 12.6$ & $273.9 \pm 15.1$ & $249.9 \pm 11.7$ & $231.2 \pm 13.8$ & 246.3 & 6.8 \\
\hline Blue WF $\left(\mathrm{L} \cdot \mathrm{kg}^{-1}\right.$ FPCM) ${ }^{h}$ & $6.3 \pm 0.4$ & $7.6 \pm 0.5$ & $7.8 \pm 0.4$ & $7.2 \pm 0.5$ & 7.4 & 0.2 \\
\hline
\end{tabular}

a Seasons (spring (1 March-31 May), summer (1 June-31 August), fall (1 September-30 November), winter (1 December-28/29 February)).

${ }^{\mathrm{b}}$ Means \pm SE $\left(n=28\right.$; $(7$ farms $\times 4$ seasons $) .{ }^{c}$ Based on Salfer et al. [19]. ${ }^{\mathrm{d}}$ Calculated based on IDF [15]. ${ }^{\mathrm{e}}$ Robinson et al. [16]; wash water includes (milk house wash water, plate cooler); units: $\mathrm{L} \cdot \mathrm{cow}^{-1} \cdot \mathrm{d}^{-1} \cdot{ }^{\mathrm{f}}$ Estimated WI values $\left(\mathrm{L} \cdot \mathrm{cow}^{-1} \cdot \mathrm{d}^{-1}\right)$ of lactating cows based on Murphy et al. [21] and Osborne's [20] equations along with extrapolated values from the overall average for the dry cows, heifers and calves. ${ }^{g}$ Calculated for summer season only. ${ }^{\mathrm{h}} \mathrm{L}$ of water $=\mathrm{kg}$ of water.

The greatest amount of water was used in the summer $\left(273.9 \pm 15.1 \mathrm{~L} \cdot \mathrm{cow}^{-1} \cdot \mathrm{d}^{-1}\right)$ followed by fall $\left(249.9 \pm 11.7 \mathrm{~L} \cdot \mathrm{cow}^{-1} \cdot \mathrm{d}^{-1}\right)$, spring $\left(231.7 \pm 12.6 \mathrm{~L} \cdot \mathrm{cow}^{-1} \cdot \mathrm{d}^{-1}\right)$ and winter $\left(231.2 \pm 13.8 \mathrm{~L} \cdot \mathrm{cow}^{-1} \cdot \mathrm{d}^{-1}\right)$. In the summer, water use was governed by WI $(64.4 \%)$ followed by wash water (32.4\%) and spray water (3.2\%). 
The average amount of WI was affected significantly $(p<0.000)$ by the season and farm management practices (represented by herd size, housing style, milking systems and the implementation of conservation practices) and was higher in summer compared to any other season similar to Brugger and Dorsey [38]. The main contributor to the total amount of utilized water was the WI due to its importance in maintaining the performance and health of the dairy herd [39].

\subsubsection{Blue WF}

The blue WF of the seven Ontario dairy farms was calculated based on the WI data of different animal categories along with washing, spray use data and feed moisture content.

The average blue WF $\left(\mathrm{L} \cdot \mathrm{kg}^{-1}\right)$ was calculated to be $7.4 \pm 0.2 \mathrm{~L} \cdot \mathrm{kg}^{-1}$. Both season and farm management strategies affected the blue WF $(p<0.00)$. On a seasonal basis, the blue WF was the highest during the fall $\left(7.8 \pm 0.4 \mathrm{~L} \cdot \mathrm{kg}^{-1}\right)$ due to a low MY followed by the summer $\left(7.6 \pm 0.5 \mathrm{~L} \cdot \mathrm{kg}^{-1}\right)$, winter $\left(7.2 \pm 0.5 \mathrm{~L} \cdot \mathrm{kg}^{-1}\right)$ and spring $\left(6.3 \pm 0.4 \mathrm{~L} \cdot \mathrm{kg}^{-1}\right)$.

Compared to other studies, Huang et al. [40] found that the average blue WF of milk was $11.0 \mathrm{~L} \cdot \mathrm{kg}^{-1}$. Ridoutt et al. [41] reported a blue WF of $14.4 \mathrm{~L} \cdot \mathrm{kg}^{-1}$ (milk) in Australia. The average blue WF in the current study was comparable with Le Riche et al. [25] and VanderZaag et al. [35]. Le Riche et al. [25] found that the blue WF was 5.54 to $6.19 \mathrm{~L} \cdot \mathrm{kg}^{-1}$, while VanderZaag et al. [35] reported $5.35 \mathrm{~L} \cdot \mathrm{kg}^{-1}$. The blue WF values reported by Le Riche et al. [25] and VanderZaag et al. [35] reflected the condition of a single farm with a mixture of pasture and indoor housing systems and an average milk production of 34.8 and $29.0 \mathrm{~kg} \cdot \mathrm{cow}^{-1} \cdot \mathrm{d}^{-1}$, respectively. Accordingly, with other factors represented by farm-to-farm variability in wash water use and re-use of plate cooler water.

Our results suggest that the blue WF value varied with respect to farm type (confined, mix) [42], type of milking system, herd size, moisture content of feed (irrigated) along with weather conditions and other management strategies, including the use of spray water to mitigate heat stress during the summer months.

However, the blue WF associated with animal feed showed that there were variations in the amount of water used across Canadian provinces. Basically, the blue water used for feed production in some regions represented by that used for irrigation at specific times during the growing season. Water can also be used in a closed environment such as greenhouses for spraying and washing [34]. In Canada, the agricultural activities accounted for only $9 \%$ of the total amount of utilized water [43].

\subsubsection{AgriSuite Software and the Potential of Water Conservation Strategies}

AgriSuite simulated the amount of water generated from milk house operations based on the herd size and the type of milking system. The decision support system can assist with identifying water conservations strategies, including evaluating the effect of reusing the plate cooler water and recycling milk house wash water to clean the holding floor area.

Based on these strategies, the total of farm water use could be reduced to $182.7 \pm 5.1 \mathrm{~L} \cdot \mathrm{cow}^{-1} \cdot \mathrm{d}^{-1}$, given that the average wash water for the milk house was $16.6 \pm 0.1 \mathrm{~L} \cdot \mathrm{cow}^{-1} \cdot \mathrm{d}^{-1}$. This represented $9.1 \%$ of the total water used and a $77.7 \%$ reduction in the milk house wash water. Accordingly, the blue WF reduced to $5.8 \pm 0.1 \mathrm{~L}^{\circ} \mathrm{kg}^{-1}$, representing a $21.6 \%$ reduction through the adoption of these conservation strategies.

Farmers are willing to implement water conservation strategies [16] as the expenses associated with choosing the appropriate type of system, including increasing the capacity of reservoirs to retain the plate cooler water, is a one-time cost. However, it is important to identify the best strategies that are both practical and beneficial to the farm.

\section{Conclusions}

The blue WF is an important sustainability indicator related to milk production. It is largely influenced by atmospheric conditions and farm management strategies that affect milk production and water use. The blue WF should be seen more broadly as an environmental indicator for food production systems. 
The outputs of this study showed that the total water use $\left(\mathrm{L}\right.$ of water $\left.\cdot \operatorname{cow}^{-1} \cdot \mathrm{d}^{-1}\right)$ and the average blue WF ( $\mathrm{L}$ of water $\cdot \mathrm{kg}^{-1}$ of FPCM) were $246.3 \pm 6.8 \mathrm{~L} \cdot \mathrm{cow}^{-1} \cdot \mathrm{d}^{-1}$ and $7.4 \pm 0.2 \mathrm{~L} \cdot \mathrm{kg}^{-1}$, respectively. Through adaptive water conservation measures, the total water use and the blue WF could be reduced by $25.8 \%$ and $21.6 \%$, respectively.

Knowing these values for regions across the world is important to improve the sustainability of milk production and improve its production from a water use perspective. This can be achieved by reducing the blue WF through adopting various water conservation options.

Understanding the current conditions of dairy farms and encouraging farmers to adopt various water conservation strategies are critical for improving the sustainability and profitability of the dairy sector.

Author Contributions: Conceptualization, M.A.-B., R.G., V.O., A.V. and M.D.; methodology, M.A.-B., V.O. and T.W.; software, T.W. and M.A.-B.; validation, M.A.-B. and T.W.; formal analysis, M.A.-B.; investigation, M.A.-B., V.O., T.W. and R.G.; resources, M.A.-B., R.G., T.W., A.V. and V.O.; writingoriginal draft preparation, M.A.-B.; writing—review and editing, R.G., M.D., A.V., V.O. and T.W. All authors have read and agreed to the published version of the manuscript.

Funding: This research was funded by the Agriculture and Agri-Food Canada and the Dairy Farmers of Canada.

Institutional Review Board Statement: Not applicable.

Informed Consent Statement: Not applicable.

Data Availability Statement: Not applicable.

Acknowledgments: The authors acknowledge the support of the Kuwait Institute for Scientific Research, the University of Guelph, the University of Windsor and Wilfrid Laurier University.

Conflicts of Interest: The authors declare no conflict of interest.

\section{References}

1. Owusu-sekyere, E.; Scheepers, M.E.; Jordaan, H. Water Footprint of Milk Produced and Processed in South Africa: Implications for Policy-Makers and Stakeholders along the Dairy Value Chain. Water 2016, 8, 322. [CrossRef]

2. Mekonnen, M.M.; Hoekstra, A.Y. The green, blue and grey water footprint of farm animals and animal products. In Value of Water Research Report Series; Twente Water Centre, University of Twente: Enschede, The Netherlands, 2010; Volume 48, p. 1.

3. Strzepek, K.; Boehlert, B. Competition for water for the food system. Philos. Trans. R. Soc. B Biol. Sci. 2010, 365, 2927-2940. [CrossRef] [PubMed]

4. Palhares, J.C.P.; Pezzopane, J.R.M. Water footprint accounting and scarcity indicators of conventional and organic dairy production systems. J. Clean. Prod. 2015, 93, 299-307. [CrossRef]

5. Hoekstra, A.Y.; Chapagain, A.K. Globalization of Water: Sharing the Planet's Freshwater Resources; Blackwell Publishing Ltd.: Oxford, UK, 2008. [CrossRef]

6. Mekonnen, M.M.; Hoekstra, A.Y. Water footprint benchmarks for crop production: A first global assessment. Ecol. Indic. 2014, 46, 214-223. [CrossRef]

7. OMAFRA. Ontario's Agricultural Planning Tools Suite (AgriSuite). 2020. Available online: http://www.omafra.gov.on.ca/ english/nm/nman/agrisuite.htm (accessed on 16 May 2020).

8. Piquette, S. The Water-Use Efficiency of Dairy Farming in Eastern Ontario: A Case Study; Carlton University: Ottawa, ON, USA, 2015.

9. Statistic Canada. Environment 2018. Available online: https://www.statcan.gc.ca/pub/11-402-x/2011000/chap/env/env-eng. htm (accessed on 24 May 2020).

10. Zonderland-Thomassen, M.A.; Ledgard, S.F. Water footprinting-A comparison of methods using New Zealand dairy farming as a case study. Agric. Syst. 2012, 100, 30-40. [CrossRef]

11. James, L.; Wescoat, J. Searching for comparative international water research: Urban and rural water conservation research in India and the United States. Water Altern. 2014, 7, 199-219.

12. House, H.K.; Hawkins, B.C.; Barkes, B.C. Measuring and Characterizing On-Farm Milking Centre Washwater Volumes; ASABE Paper No. 1908138; ASABE Publ.: St. Joseph, MI, USA, 2014. 
13. Hoekstra, A.Y.; Chapagain, A.K.; Aldaya, M.M.; Mekonnen, M.M. The Water Footprint Assessment Manual: Setting the Global Standard; Earthscan: London, UK; Washington, DC, USA, 2011; Available online: https:/ / waterfootprint.org/media/downloads / TheWaterFootprintAssessmentManual_2.pdf (accessed on 15 June 2020).

14. Palhares, J.C.P.; Novelli, T.I.; Morelli, M. Best practice production to reduce the water footprint of dairy milk. Rev. Ambiente Ãgua 2020, 15, 1-10. Available online: http:/ / www.scielo.br/scielo.php?script=sci_arttext\&pid=S1980-993X2020000100308\&nrm=iso (accessed on 15 June 2020). [CrossRef]

15. IDF. A Common Carbon Footprint Approach for Dairy: The IDF Guide to Standard Lifecycle Assessment Methodology for the Dairy Sector; International Dairy Federation: Brussels, Belgium, 2015; Volume 7. [CrossRef]

16. Robinson, A.D.; Gordon, R.J.; VanderZaag, A.C.; Rennie, T.J.; Osborne, V.R. Usage and attitudes of water conservation on Ontario dairy farms. Prof. Anim. Sci. 2016, 32, 236-242. Available online: https://core.ac.uk/download/pdf/82196148.pdf (accessed on 16 February 2021). [CrossRef]

17. Aziz, D.; Alkass, J.; Hermiz, H. Adjustment factors for growth traits in Awassi sheep. Indian J. Anim. Sci. 1989, 59, 1285-1289.

18. Yapi-Gnaoré, C.; Oya, A.; Rege, E.; Dagnogo, B. Analysis of an open nucleus breeding programme for Djallonkè sheep in the Ivory Coast. 1. Examination of non-genetic factors. Anim. Sci. 1997, 64, 291-300. [CrossRef]

19. Salfer, I.J.; Dechow, C.D.; Harvatine, K.J. Annual rhythms of milk and milk fat and protein production in dairy cattle in the United States. J. Dairy Sci. 2019, 102, 742-753. [CrossRef] [PubMed]

20. Osborne, V.R. Water, the Forgotten Nutrient. WCDS Adv. Dairy Technol. 2006, 18, 197-210.

21. Murphy, M.R.; Davis, C.L.; McCoy, G.C. Factors Affecting Water Consumption by Holstein Cows in Early Lactation1. J. Dairy Sci. 1983, 66, 35-38. [CrossRef]

22. Chase, L.E.; Sniffen, C.J. Equations Used in "ANAL-FEED" a VisiCal Template; Department of Animal Science, Mimeo, Cornell University: Ithaca, NY, USA, 1985.

23. Holstein Canada. The Holstein Breed. 2015. Available online: https://www.holstein.ca/Public/en/About_Us/The_Canadian_ Dairy_Industry/The_Holstein_Breed (accessed on 20 June 2020).

24. Ward, D.; McKague, K. Water Requirements of Livestock; Ontario Ministry of Agriculture, Food and Rural Affairs: Guelph, ON, Canada, 2019; Agdex\#:716/400.

25. Le Riche, E.L.; VanderZaag, A.C.; Burtt, S.; Lapen, D.; Gordon, R. Water use and conservation on a free-stall dairy farm. Water 2017, 9, 977. [CrossRef]

26. Djemali, M.; Aloulou, R.; Sassi, M.B. Adjustment factors and genetic and phenotypic parameters for growth traits of Barbarine lambs in Tunisia. Small Rumin. Res. 1994, 13, 41-47. [CrossRef]

27. Kurowska, Z.; Danell, Ö. Adjusting Lamb Weight for Age of Ewe, Litter Size, Sex and Age of Lamb in the Swedish Sheep Recording Scheme. Acta Agric. Scand. Sect. A-Anim. Sci. 1992, 42, 82-90. [CrossRef]

28. NASA. Power Project Data Sets. 2019. Available online: https://power.larc.nasa.gov/data-access-viewer/ (accessed on 10 May 2020).

29. Lefcourt, A.M.; Schmidtmann, E.T. Body Temperature of Dry Cows on Pasture: Environmental and Behavioral Effects. J. Dairy Sci. 1989, 72, 3040-3049. [CrossRef]

30. St-Pierre, N.R.; Cobanov, B.; Schnitkey, G. Economic Losses from Heat Stress by US Livestock Industries. J. Dairy Sci. 2003, 86, E52-E77. [CrossRef]

31. R Development Core Team. R: A Language and Environment for Statistical Computing; R Development Core Team: Vienna, Austria, 2013.

32. Kume, S.; Nonaka, K.; Oshita, T.; Kozakai, T. Evaluation of drinking water intake, feed water intake and total water intake in dry and lactating cows fed silages. Livest. Sci. 2010, 128, 46-51. [CrossRef]

33. Cardot, V.; Le Roux, Y.; Jurjanz, S. Drinking Behavior of Lactating Dairy Cows and Prediction of Their Water Intake. J. Dairy Sci. 2008, 91, 2257-2264. [CrossRef]

34. Beaulieu, M.S.; Fric, C.; Soulard, F. Estimation of Water Use in Canadian Agriculture in 2001; Statistics Canada: Ottawa, ON, Canada, 2001. Available online: https://www.gov.mb.ca/waterstewardship/licensing/wlb/pdf/sc_estimation_of_water_use_in_ canadian_agriculture_2001.pdf (accessed on 15 May 2020).

35. VanderZaag, A.C.; Burtt, S.; Vergé, X.; Piquette, S.; Wright, T.; Kroebel, R.; Gordon, R. Case Study: Water budget of a dairy farm with a tie-stall barn for milk cows and summer pasturing of heifers and dry cows. Prof. Anim. Sci. 2018, 34, 108-117. [CrossRef]

36. Doreau, M.; Corson, M.S.; Wiedemann, S.G. Water use by livestock: A global perspective for a regional issue? Anim. Front. 2012, 2, 9-16. [CrossRef]

37. Higham, C.D.; Horne, D.; Singh, R.; Scarsbrook, M.R. Water use on nonirrigated pasture-based dairy farms: Combining detailed monitoring and modeling to set benchmarks. J. Dairy Sci. 2017, 100, 828-840. [CrossRef]

38. Brugger, M.; Dorsey, B. Using Water Meters to Reduce Dairy Farm Water Use. In Livestock Environment VIII, 31 August-4 September 2008, Iguassu Falls, Brazil; American Society of Agricultural and Biological Engineers: St. Joseph, MI, USA, 2008. [CrossRef]

39. National Research Council (NRC). Nutrient Requirements of Dairy Cattle, 7th ed.; National Research Council: Washington, DC, USA, 2001.

40. Huang, J.; Xu, C.C.; Ridoutt, B.G.; Liu, J.J.; Zhang, H.L.; Chen, F.; Li, Y. Water availability footprint of milk and milk products from large-scale dairy production systems in Northeast China. J. Clean. Prod. 2014, 79, 91-97. [CrossRef] 
41. Ridoutt, B.; Williams, S.R.O.; Baud, S.; Fraval, S.; Marks, N. Short communication: The water footprint of dairy products: Case study involving skim milk powder. J. Dairy Sci. 2010, 93, 5114-5117. [CrossRef]

42. Mekonnen, M.M.; Hoekstra, A.Y. A Global Assessment of the Water Footprint of Farm Animal Products. Ecosystems 2012, 15, 401-415. [CrossRef]

43. Statistics Canada. Human Activity and the Environment, Annual Statistics; Catalogue no. 16-201-XPE; Statistics Canada: Ottawa, ON, Canada, 2003. 